\title{
Fluoroscopy-induced chronic radiation dermatitis treated with excision and reconstructed with rhomboid flap
}

Eksizyonla tedavi edilen ve rhomboid flep ile rekonstrüksiyonu yapılan floroskopiye bağlı kronik radyodermatit

\section{Müge Göre Karaali, ๑ Soner Karaali*, ๑ Ayșe Esra Koku Aksu**, ๑ Mehmet Salih Gürel***}

Binali Yıldırım University, Mengücek Gazi Training and Research Hospital, Clinic of Dermatology; *Plastic Reconstructive and Aesthetic Surgery

Department, Erzincan, Turkey

**University of Health Sciences Turkey, İstanbul Training and Research Hospital, Clinic of Dermatology, İstanbul, Turkey ***Medeniyet University Faculty of Medicine, Göztepe Training and Research Hospital, Clinic of Dermatology, İstanbul, Turkey

\begin{abstract}
Fluoroscopy is widely used for minimally invasive procedures. The diagnosis of fluoroscopy-induced chronic radiation dermatitis (FICRD) may be overlooked, because patients may unintentionally be exposed to radiation in surgical procedures. Prolonged or multiple procedures increase the risk of acute and chronic skin damage. Herein, we report a patient diagnosed with FICRD treated with excision and reconstructed with rhomboid flap. Due to the risk of radiation-related malignancy, complete surgical excision and suitable reconstruction according to the skin defect may be preferred as a treatment option. Clinical follow-up is important especially following prolonged fluoroscopy-guided procedures. Keywords: Fluoroscopy, radiation dermatitis, dermatologic surgery, rhomboid flap
\end{abstract}

Öz

Floroskopi özellikle minimal invaziv prosedürler için yaygın olarak kullanılmaktadır. Floroskopi ilişkili kronik radyodermatitin (FiKRD) tanısı, hastaların cerrahi prosedürlerde farkında olmadan radyasyona maruz kalması nedeniyle gözden kaçırılabilir. Uzun süren veya çoklu girişimler akut ve kronik deri hasarı riskini artııı. Burada, eksizyon ile tedavi edilen ve rhomboid flep ile rekonstrüksiyonu yapılan FiKRD tanısı konmuş bir hastayı sunuyoruz. Radyasyona bağlı malignite riski nedeniyle, cerrahi eksizyon ve defekte göre rekonstrüksiyon ile onarım bir tedavi seçeneği olarak tercih edilebilir. Özellikle uzun sureli floroskopi eşliğinde yapılan prosedürlerin ardından klinik takip önemlidir.

Anahtar Kelimeler: Floroskopi, radyodermatit, dermatolojik cerrahi, rhomboid flep

\section{Introduction}

Radiodermatitis may occur in acute, subacute or chronic forms due to exposure to ionizing radiation. Beyond radiation therapy, it has been reported with a wide use of fluoroscopy, especially for minimally invasive vascular procedures, such as; radiofrequency catheter ablation, renal angioplasty, interventional neuroradiology and implantation of cardiac defibrillator and pacemaker devices ${ }^{1}$. Fluoroscopy-induced chronic radiation dermatitis (FICRD) is a rare condition with an incidence of less than $0,01 \%$ per procedure ${ }^{2}$. The diagnosis of FICRD may be overlooked because of unawareness of the patients and the period between exposure to radiation during surgical procedures and manifestation of skin injuries varies from months up to years ${ }^{3}$. Due to the risk of cutaneous malignancy development in the affected area, awareness of this entity and early diagnosis is important ${ }^{4}$. There are no

Address for Correspondence/Yazışma Adresi: Müge Göre Karaali MD, Binali Yıldırım University, Mengücek Gazi Training and Research Hospital, Clinic of Dermatology, Erzincan, Turkey Phone: +90 5303093328 E-mail: mugegore@hotmail.com

Received/Geliş Tarihi: 10.03.2020 Accepted/Kabul Tarihi: 10.08.2020 ORCID: orcid.org/0000-0003-0645-0662

CCopyright 2020 by Turkish Society of Dermatology and Venereology

Turkderm - Turkish Archives of Dermatology and Venereology published by Galenos Yayınevi. 
ideal treatment guidelines in the literature but topical and intralesional steroids, surgical excision and reconstruction with skin grafts are the treatment options ${ }^{5,6}$. Herein, we report a patient diagnosed with FICRD treated with excision and reconstructed with rhomboid flap.

\section{Case Report}

A 68-year-old man with hypertension, diabetes mellitus and severe coronary artery disease presented with a non-healing ulcer on a firm plaque on his back for one year. He had a history of coronary angioplasty and stenting guided by fluoroscopy 7 years ago, lasting 5 hours in the first and 3 hours in consecutive days. He had undergone angioplasty again lasting 3 hours, 2 years ago. One year after the second intervention, a $5 \times 5 \mathrm{~cm}$ erythematous well-demarcated plaque appeared, and one year after that, a progressive ulcer despite topical therapies such as antiseptics, petrolatum, etc developed on the plaque. Dermatologic examination revealed a $4 \times 5 \mathrm{~cm}$ erythematous, violaceous, telangiectatic, sclerotic, indurated, rectangular-shaped plaque and a $2.5 \times 5 \mathrm{~cm}$ well-demarcated green-grey colored, necrotic, crusted ulcer on his left scapular region (Figure 1). A $4 \mathrm{~mm}$ punch biopsy showed loss of epidermis, necrobiosis, eosinophilic appearance of collagen consistent with chronic radiation dermatitis. The histopathological findings, along with the patient's history of radiation exposure, corresponding to the affected area of involvement, led to the clinical diagnosis of FICRD. Due to unresponsive treatment with topical agents and the risk of malignancy development on the lesion it was excised completely from its erythematous border and reconstructed with rhomboid flap with a good therapeutic result (Figure 2). Excisional biopsy showed chronic radiation dermatitis without malignancy. The patient was followed up 3 months for wound healing (Figure 3). Informed consent was obtained.

\section{Discussion}

Fluoroscopy enables real time vision for minimal invasive interventions for diagnostic and therapeutic purposes ${ }^{4}$. FICRD is an uncommon

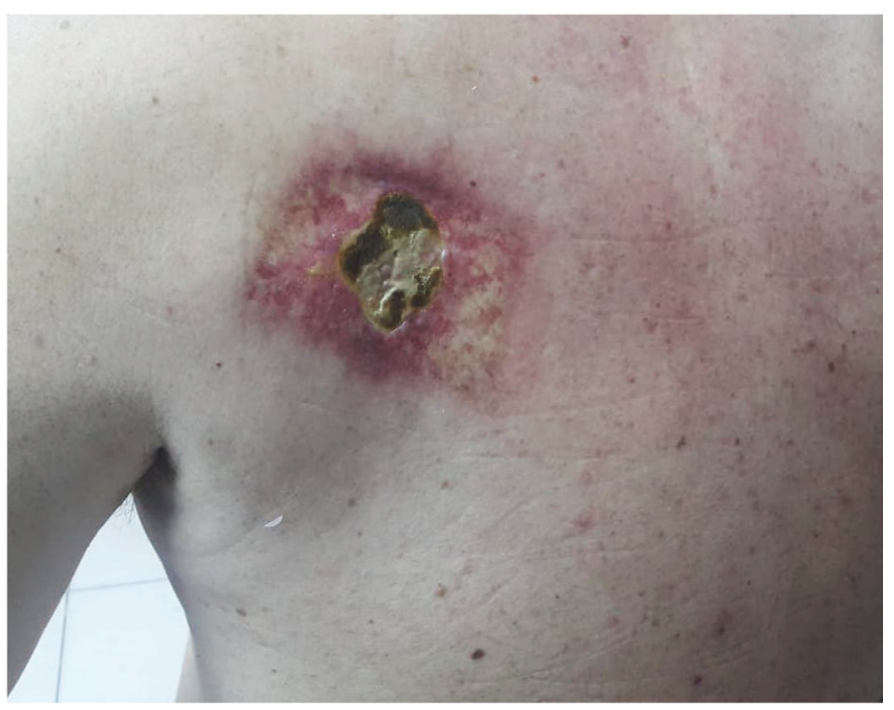

Figure 1. Dermatologic examination: A $4 \times 5 \mathrm{~cm}$ erythematous, violaceous telengiectatic, sclerotic, indurated, rectangular-shaped plaque and a $2.5 \times 5 \mathrm{~cm}$ well demarcated green-grey colored, necrotic, crusted ulcer on his left scapular region

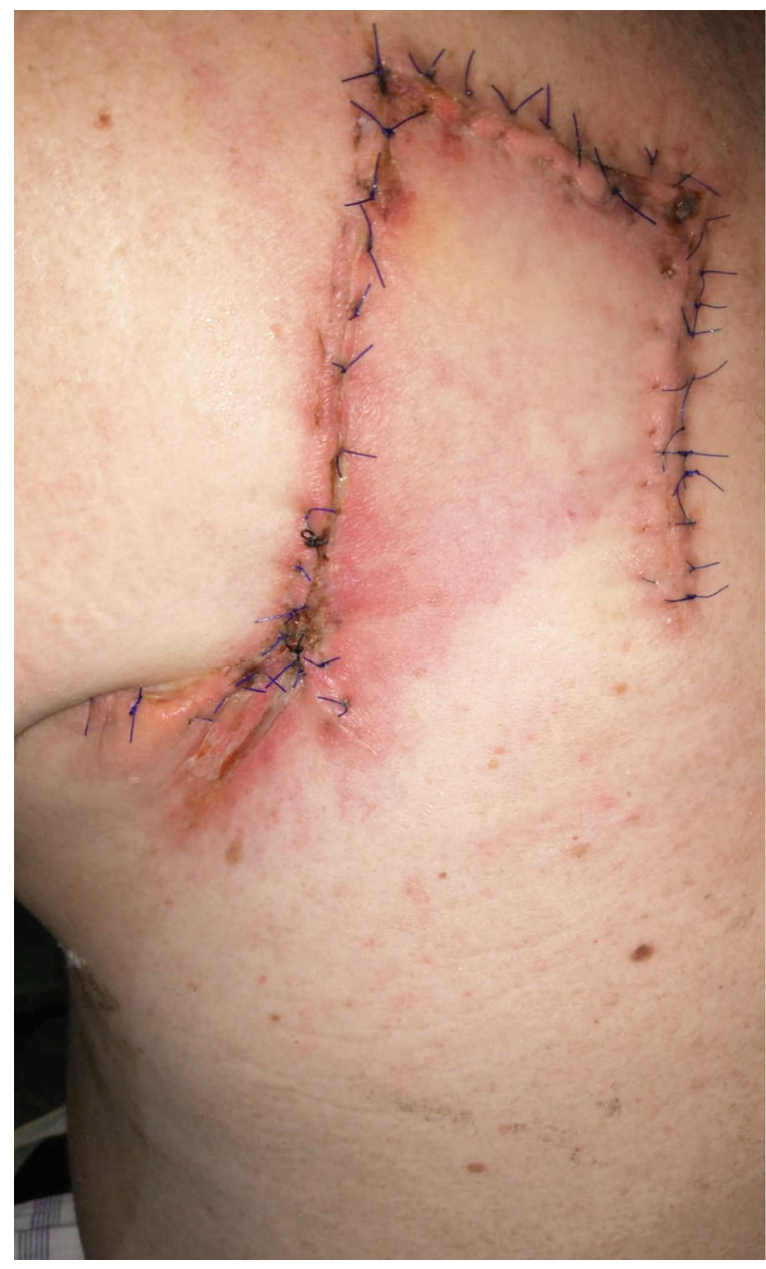

Figure 2. Reconstruction with rhomboid flap

complication of ionizing radiation. Cases of chronic radiation dermatitis due to fluoroscopy-guided interventions have been reported mostly in radiology and cardiology and rarely in dermatology literature ${ }^{1-10}$. It may be misdiagnosed due to unawareness of the patients about ionizing radiation exposure in operations, somehow late presentation of lesions from months to years, and a wide range of skin lesions 3,4 . In our case, the symptoms started six years after the first intervention and one year after the second intervention, as reported in the literature.

Skin is a radiosensitive organ. While the neck is resistant to ionizing radiation, the abdomen, back and face are more radiosensitive. During coronary interventions such as angiography and stent implantation, the scapular region receives the most ionizing radiation because of preferred projection for best vision. FICRD may be presented with erythema, atrophy, hyperpigmentation, hypopigmentation, telangiectasia, therapy resistant chronic ulcer, necrosis in a geometric or angulated shape and non-melanoma skin cancer ${ }^{4,7}$. In accordance with literature, the lesion was located on the left subscapular region in a rectangular shape.

The extent of radiodermatitis may be associated with many factors including radiation dose, repetitive interventions, interval between procedures, size and localization of irradiated region. Patient related factors are smoking habit, high body mass index, malnutrition, accompanying autoimmune diseases and medications ${ }^{8}$. FICRD may occur even after minimal exposure to fluoroscopy. It has been reported that a radiation dose of 10-12 Gy is necessary for skin injury due to 


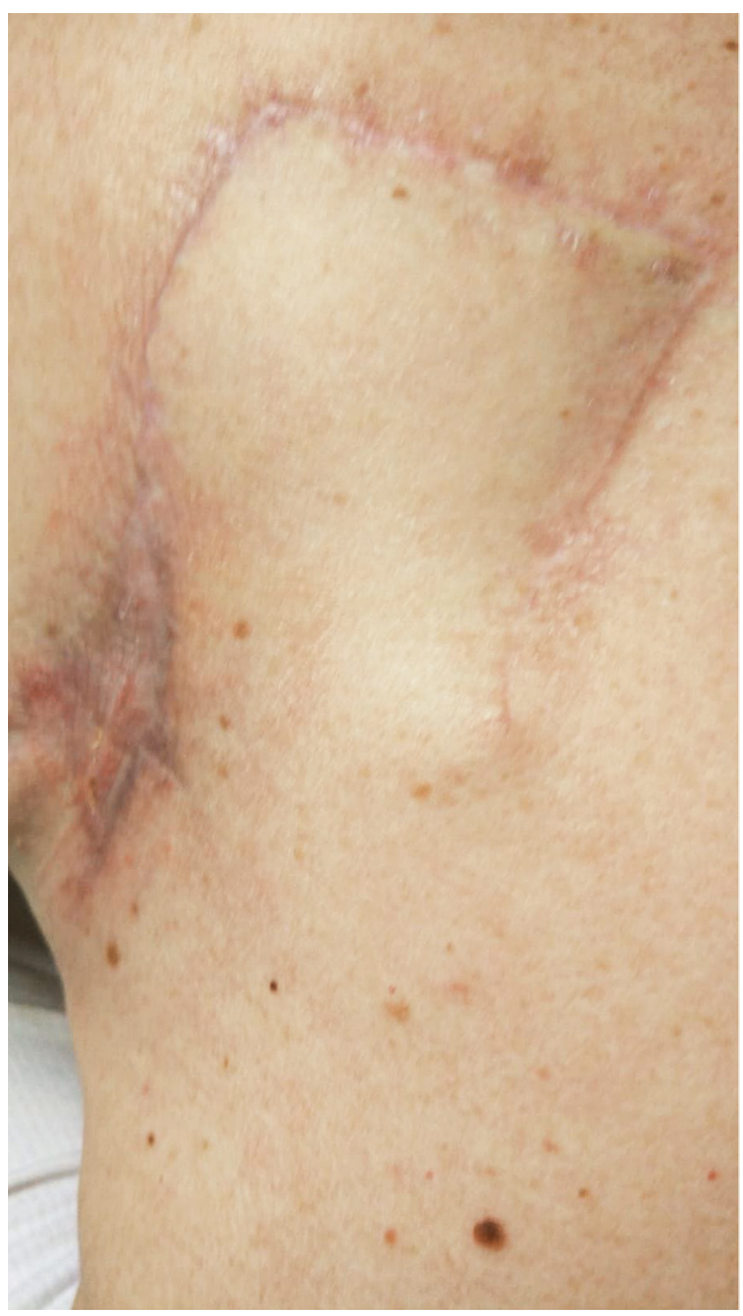

Figure 3. The lesion on third month follow-up

fluoroscopy and the mean radiation exposure in cardiac interventions is about 0.02 to $0.05 \mathrm{~Gy} /$ minute $^{9}$. According to this information the exposure to ionizing radiation of our case was totally 13.2 to 33 Gy for an 11-hour intervention and more than $12 \mathrm{~Gy}$.

Radiation related skin cancer is a well-known complication of ionizing radiation. But to the best of our knowledge, fluoroscopy related skin cancer has not been reported yet. It may be explained by the fact that in fluoroscopic interventions doses can be applied in a single fraction without skin sparing qualities while energy in conventional radiation is delivered in fractionated doses to protect the skin ${ }^{10}$. However, due to the risk of cutaneous malignancy development, awareness of this entity and early diagnosis is important and the diagnosis of FICRD should be kept in mind in the patients with a history of fluoroscopy and with characteristic skin changes, especially therapy resistant ulcers ${ }^{4}$.
The diagnosis may be confirmed by histopathology beyond history of fluoroscopy exposure and clinical appearance. Topical and intralesional steroids, surgical excision and reconstruction with skin grafts may be preferable for the treatment ${ }^{5,6}$. In conclusion, because of the rarity of FICRD, awareness of this entity is important. Due to the risk of radiationinduced malignancies, complete surgical excision and reconstruction according to the defect may be preferable as a treatment option. Clinical follow-up may be necessary especially after long fluoroscopyguided procedures.

\section{Ethics}

Informed Consent: Informed consent was obtained from the patient. Peer-review: Externally and internally peer-reviewed.

\section{Authorship Contributions}

Surgical and Medical Practices: S.K., Concept: M.G.K., S.K., M.S.G., Design: M.G.K., S.K., Data Collection or Processing: M.G.K., S.K., M.S.G., Analysis or Interpretation: M.G.K., S.K., M.S.G., Literature Search: M.G.K., A.E.K.A., Writing: M.G.K., S.K., M.S.G.

Conflict of Interest: No conflict of interest was declared by the authors.

Financial Disclosure: The authors declared that this study has received no financial support.

\section{References}

1. Herz-Ruelas ME, Gómez-Flores M, Moxica-Del Angel J, et al: Ulcerated radiodermatitis induced after fluoroscopically guided stent implantation angioplasty. Case Rep Dermatol Med 2014;2014:768624.

2. Kirkwood ML, Arbique GM, Guild JB: et al. Radiation-induced skin injury after complex endovascular procedures. J Vasc Surg 2014;60:742-8.

3. Falay T, Erdemir VA, Savas $S$, et al: Fluoroscopy induced chronic radiodermatitis. J Dermatol Res Ther 2016:2:031.

4. Aerts A, Decraene T, van den Oord JJ, et al: Chronic radiodermatitis following percutaneous coronary interventions: a report of two cases. J Eur Acad Dermatol Venereol 2003;17:340-3.

5. Koenig TR, Wolff D, Mettler FA, et al: Skin injuries from fluorosopically guided procedures: part 1, characteristics of radiation injury. AJR Am J Roentgenol 2001;177:3-11.

6. Koenig TR, Mettler FA, Wagner LK: Skin injuries from fluoroscopically guided procedures: part 2, review of 73 cases and recommendations for minimizing dose delivered to patients. AJR Am J Roentgenol 2001;177:13-20.

7. Henry MF, Maender JL, Shen $Y$, et al: Fluoroscopy-induced chronic radiation dermatitis: a report of three cases. Dermatol Online J 2009;15:3.

8. Balter S, Hopewell JW, Miller DL, et al: Fluoroscopically guided interventional procedures: a review of radiation effects on patients' skin and hair. Radiology 2010;254:326

9. Miller DL, Balter $S$, Noonan PT, et al: Minimizing radiation-induced skin injury in interventional radiology procedures. Radiology 2002;225:329-36.

10. Lee J, Hoss D, Phillips TJ: Fluoroscopy-induced skin necrosis. Arch Dermatol 2003;139:140-1. 